\title{
The Bacillus subtilis cysP gene encodes a novel sulphate permease related to the inorganic phosphate transporter (Pit) family
}

\author{
Maria Cecilia Mansilla and Diego de Mendoza
}

Instituto de Biología Molecular y Celular de Rosario (IBR-CONICET) and Departamento de Microbiología, Facultad de Ciencias Bioquímicas y Farmacéuticas, Universidad Nacional de Rosario, Suipacha 531, 2000-Rosario, Argentina
Author for correspondence: Diego de Mendoza. Tel: +54 341 4350596. Fax: +54 3414390465. e-mail: diegonet@citynet.net.ar

\begin{abstract}
Sulphate permeases in the plasma membrane are responsible for uptake of environmental sulphate used in the sulphate assimilation pathway in bacteria and plants. Here it is reported that the ORF designated cysP, located on the Bacillus subtilis chromosome between cys $H$ and five putative genes involved in sulphate assimilation, encodes a sulphate permease. cysP is able to complement Escherichia coli cysteine auxotrophs with mutations affecting either the membrane or periplasmic components of the sulphate-thiosulphate permease. Transport studies with cell suspensions of a cysA97 E. coli strain transformed with a plasmid expressing the $B$. subtilis cys $P$ gene indicated that CysP catalyses sulphate uptake. Analysis of the primary sequence showed that CysP (354 amino acids, estimated molecular mass $24 \mathrm{kDa}$ ) is a highly hydrophobic protein which has 11 putative transmembrane helices. Sequence comparisons revealed that CysP, together with the phosphate permease of Neurospora crassa, Pho-4, and E. coli PitA, belongs to the family of related transporters, the inorganic phosphate transporter (Pit) family. Among the putative phosphate permeases, CysP shows a similar size and the same domain organization as the archaeal transporters. This is the first report of a sulphate permease in a Gram-positive organism.
\end{abstract}

Keywords: Bacillus subtilis, cysteine biosynthesis, sulphate, transport

\section{INTRODUCTION}

In many micro-organisms and higher plants sulphur metabolism is initiated by the uptake of sulphate from the environment. These organisms assimilate sulphate into cysteine, the first sulphur-containing amino acid, and various sulphur-containing secondary metabolites (Kredich, 1996). Thus, uptake of sulphate by cells is considered to be the key entry step of the sulphur cycle in nature. Because the sulphate transport system is involved in this initial step, it should play a central role in the regulation of the entire sulphur metabolism pathway by controlling the import of available sulphate. Among bacterial sulphate transporters, those from Escherichia coli and Salmonella typhimurium are the best studied. These micro-organisms possess an ATPbinding cassette (ABC)-type sulphate-thiosulphate transport system (Higgins, 1992), which is controlled in parallel with cysteine biosynthetic enzymes and which is a part of the cysteine regulon; gene expression of this

Abbreviation: TMS, transmembrane segment. region requires sulphur limitation and a positive regulator, CysB, the product of the cysB gene (Kredich, 1996). Components of the sulphate-thiosulphate permease from E. coli and S. typhimurium are encoded by the contiguous genes $c y s P, c y s T, c y s W$ and $c y s A$, and by the unlinked gene $s b p$ (Kredich, 1996). The products of $c y s T$ and $c y s W$ span the membrane and form a channel for the passage of sulphate and related ions, cys $A$ encodes a hydrophilic membrane-associated ATP-binding protein, and $s b p$ and $c y s P$ encode the sulphate and thiosulphate periplasmic binding proteins, respectively (Hryniewicz et al., 1990; Sirko et al., 1990). Molecular analysis of sulphate transport in Synechococcus sp., a cyanobacterium, established a four-component membrane sulphate transport system, essentially similar to that of E. coli (Laudenbach \& Grossman, 1991).

The Neurospora crassa cys- $14^{+}$gene, the first eukaryotic sulphate transporter gene to be cloned, encodes a protein of approximately $90 \mathrm{kDa}$ with 12 putative hydrophobic membrane-spanning domains (Ketter et al., 1991). The CYS14 protein is localized within the plasma membrane fraction and its synthesis depends on sulphur depri- 


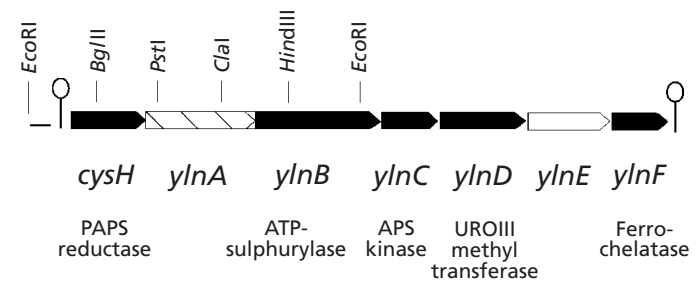

$1 \mathrm{~kb}$

Fig. 1. Genetic organization of the $B$. subtilis operon containing $y \ln A$. The ORFs encoding enzymes similar to those of cysteine biosynthesis are shaded. The arrows indicate the direction of gene transcription. Relevant restriction sites are indicated.

vation. Additional genes that encode $\mathrm{H}^{+}$/sulphate cotransporters have been identified in Homo sapiens (Hastbacka et al., 1994), the tropical legume Stylosanthes hamata (Smith et al., 1995a), Saccharomyces cerevisiae (Smith et al., 1995b), Mus musculus (Kobayashi et al., 1997), Arabidopsis thaliana (Takahashi et al., 1997) and Yersinia enterocolitica (Hoffmann et al., 1998). All of them show significant homology to each other and, together with CYS14, represent a family of membrane transport proteins, the sulphate permease (SulP) family.

In contrast to the knowledge of the sulphate transport system in Gram-negative bacteria and several eukaryotes, no information is available about the genes or the transport proteins involved in sulphate uptake in Bacillus subtilis or other Gram-positive organisms. We have recently reported the isolation of the $B$. subtilis cys $H$ gene, whose product is $3^{\prime}$-phosphoadenosine $5^{\prime}$ phosphosulphate (PAPS) sulphotransferase and whose expression is repressed by cysteine and sulphide and induced by sulphur limitation (Mansilla \& de Mendoza, 1997). A partial DNA sequence downstream of $c y s H$ revealed a second ORF, called ORF2, that gave a deduced amino acid sequence similar to that of a putative phosphate permease. As a result of the $B$. subtilis genome sequencing project, the complete nucleotide sequence of ORF2 was determined (Kunst et al., 1997). This ORF was named $y \ln A$; its gene product has 354 amino acids and it has a predicted molecular mass of $42 \cdot 3 \mathrm{kDa}$. Both the $c y s H$ and $y \ln A$ genes form part of a 6074 bp putative operon containing seven ORFs (Fig. 1). It has been demonstrated that three of these ORFs encode enzymes involved in cysteine biosynthesis : $c y s H$ encodes the PAPS sulphotransferase (Mansilla \& de Mendoza, 1997), whilst $y \ln D$ and $y \ln F$ encode proteins involved in synthesis of sirohaem, a cofactor of sulphite reductase (Johansson \& Hederstedt, 1999). $y \ln B$ and $y \ln C$ appear to be homologous to ATP-sulphurylase and adenosine 5'-phosphosulphate (APS) kinase, respectively, whilst $y \ln E$ does not show significant homology with any known protein contained in the databases.

In this report we show that $y \ln A$ encodes a membraneassociated protein able to restore the capacity of E. coli mutants unable to transport sulphate to grow in minimal media with sulphate as a sulphur source. In addition, we demonstrate that the $B$. subtilis $y \ln A$ gene encodes a permease required for sulphate uptake, rather than a phosphate permease.

\section{METHODS}

Bacterial strains, plasmids and growth conditions. The bacterial strains and plasmids used in this study are listed in Table 1. E. coli and B. subtilis strains were routinely grown in Luria-Bertani (LB) broth (Sambrook et al., 1989). The minimal medium used for E. coli was M9 (Miller, 1972) supplemented with $0 \cdot 4 \%$ glucose, $2 \mathrm{mM} \mathrm{MgSO}$, $0 \cdot 001 \mathrm{mM}$ $\mathrm{CaCl}_{2}$ and $0.01 \%$ thiamin. For nutritional studies, $\mathrm{MgCl}_{2}$ replaced $\mathrm{MgSO}_{4}$, and glutathione $(1 \mathrm{mM})$ or cystine $(1 \mathrm{mM})$ were used as sulphur sources. Antibiotics were added to media as follows: $100 \mu \mathrm{g}$ ampicillin $\mathrm{ml}^{-1}, 5 \mu \mathrm{g}$ chloramphenicol $\mathrm{ml}^{-1}$. Spizizen salts (Spizizen, 1958), supplemented with $0.5 \%$ glucose and the required L-amino acids, was used as the minimal medium for B. subtilis. In nutritional studies, where different sulphur sources were tested, $\mathrm{MgSO}_{4}$ and $\left(\mathrm{NH}_{4}\right)_{2} \mathrm{SO}_{4}$ were substituted by an equimolar amount of $\mathrm{MgCl}_{2}$ and $\mathrm{NH}_{4} \mathrm{Cl}$, respectively.

Chromate resistance was tested on LB agar plates to which sterile $0.25 \mathrm{mM} \mathrm{K}_{2} \mathrm{CrO}_{4}$ was added (Pardee et al., 1966).

Plasmid constructions. Plasmid preparations, restriction enzyme digestions and agarose gel electrophoresis were carried out according to methods described by Sambrook et al. (1989). Competent E. coli cells were transformed with supercoiled plasmid DNA by using the calcium chloride procedure or by electroporation (Sambrook et al., 1989).

Expression analysis. Recombinant plasmids containing the appropriate DNA fragments under T7 promoter control were transformed into $E$. coli BL21( $\lambda \mathrm{DE} 3)$. Induction of gene expression was done as described by Studier et al. (1990). Briefly, mid-exponential-phase cultures $(1 \mathrm{ml})$ of BL21( $\lambda$ DE3) carrying plasmids pBluescript II SK(+) or pBS181 were induced by adding $1 \mathrm{mM}$ IPTG. After $10 \mathrm{~min}$ the cultures received rifampicin $\left(100 \mu \mathrm{g} \mathrm{ml}^{-1}\right)$ to inhibit mRNA synthesis from the E. coli chromosome. After further incubation for $1 \mathrm{~h}$, they were labelled with $1 \mu \mathrm{Ci}\left[{ }^{35} \mathrm{~S}\right]$ methionine [specific activity $\left.1000 \mathrm{Ci} \mathrm{mmol}{ }^{-1}\left(37 \mathrm{TBq} \mathrm{mmol}^{-1}\right)\right]$. After $10 \mathrm{~min}$, the cells were harvested by centrifugation, washed twice with $10 \mathrm{mM}$ Tris/ $\mathrm{HCl}$ buffer $(\mathrm{pH} 7 \cdot 4)$, and stored frozen until analysis. Cells were resuspended in $30 \mathrm{mM}$ Tris/ $\mathrm{HCl}$ buffer $(\mathrm{pH} 7 \cdot 4$ ) containing $10 \mathrm{mM} \mathrm{MgCl} 2$ and $1 \mathrm{mM} \mathrm{PMSF}$, and disrupted by sonication (four or five $10 \mathrm{~s}$ bursts) using a VibraCell Ultrasonic Processor (Sonics \& Materials). The extracts were centrifuged at $190000 \mathrm{~g}$ for $1 \mathrm{~h}$, and labelled proteins present in either soluble or membrane fractions were separated by SDS-PAGE and detected by autoradiography.

Assay of sulphate transport. Cultures of strain JM2314 carrying relevant plasmids were grown in M9 minimal medium supplemented with glutathione as sulphur source to exponential phase. Cells were collected, washed and then resuspended in Davis salts (Miller, 1972) and incubated for $5 \mathrm{~min}$ at $30^{\circ} \mathrm{C}$. The measurement of sulphate transport was performed by incubating at $30^{\circ} \mathrm{C}$ a cell suspension containing $10^{8}$ cells ml ${ }^{-1}, 30 \mu \mathrm{g}$ chloramphenicol ml ${ }^{-1}, 0 \cdot 01 \mathrm{mM}$ sodium sulphate and approximately $10^{6}$ c.p.m. ${ }^{35} \mathrm{SO}_{4}^{2-} \mathrm{ml}^{-1}(1050 \mathrm{Ci}$ $\left.\mathrm{mmol}^{-1}\right)$. The incubation period was terminated by filtering the cell suspension through a $0.45 \mu \mathrm{m}$ Millipore filter. The filters were washed with $5 \mathrm{ml}$ Davis salts. Filters were 
Table 1. Bacterial strains and plasmids used in this study

\begin{tabular}{|c|c|c|}
\hline Strain or plasmid & Relevant characteristic(s) & Source or reference \\
\hline \multicolumn{3}{|l|}{ Bacillus subtilis } \\
\hline JH642 & $\operatorname{trp} C 2$ pheA1 & Laboratory stock \\
\hline \multicolumn{3}{|l|}{ Escherichia coli } \\
\hline DH $5 \alpha$ & $\begin{array}{l}\text { supE44 thi-1 } \Delta \text { lacU169( } \phi 80 \mathrm{~d} l a c Z \Delta \mathrm{M} 15) \text { endA1 recA1 } \\
\text { hsdR17 gyrA96 relA1 }\end{array}$ & Laboratory stock \\
\hline BL21 $(\lambda \mathrm{DE} 3)$ & $\mathrm{F}^{-}$ompT $\mathrm{r}_{\mathrm{B}}^{-} \mathrm{m}_{\mathrm{B}}^{-} \mathrm{pLys}$ & Laboratory stock \\
\hline JM2314 & cysA97 & CGSC* \\
\hline EC2402 & $s b p c y s P$ & Sirko et al. (1995) \\
\hline EC2256 & $\begin{array}{l}\mathrm{F}^{\prime} \text { araD319 } \Delta \text { lacU169 rpsL thi fla trp6 cysT329: : lac } \\
\text { inm }^{\lambda \mathrm{p} 1(209)}\end{array}$ & $\begin{array}{l}\text { Hryniewicz et al. } \\
\text { (1990) }\end{array}$ \\
\hline \multicolumn{3}{|l|}{ Plasmids } \\
\hline $\begin{array}{l}\text { pBluescript II } \\
\mathrm{SK}(+)\end{array}$ & E. coli cloning vector, $\mathrm{Amp}^{\mathrm{R}}$ & Stratagene \\
\hline pBS170 & $\begin{array}{l}3.4 \mathrm{~kb} E c o \mathrm{RI}-E c o \mathrm{RI} \text { fragment of chromosomal DNA } \\
\text { of JH642 cloned into pBluescript II SK }(+)\end{array}$ & $\begin{array}{l}\text { Mansilla \& de } \\
\text { Mendoza (1997) }\end{array}$ \\
\hline pBS181 & $\begin{array}{l}1.98 \mathrm{~kb} B g l \mathrm{II}-\text { HindIII fragment of pBS170 cloned } \\
\text { into pBluescript II } \mathrm{KS}(+) \text { digested with } \\
\text { BamHI/HindIII }\end{array}$ & This study \\
\hline pBS184 & $\begin{array}{l}2 \cdot 2 \mathrm{~kb} P s t \mathrm{I}-P s t \mathrm{I} \text { fragment of } \mathrm{pBS} 170 \text { (extending from } \\
\text { the Pst } \mathrm{I} \text { site in } y \ln A \text { to the Pst } \mathrm{I} \text { site in the } \mathrm{pBS} 170 \\
\text { polylinker) cloned into pBluescript II KS }(+) \\
\text { digested with } P \text { st } \mathrm{I}\end{array}$ & This study \\
\hline pBS188 & 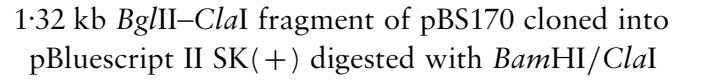 & This study \\
\hline pBS190 & $\begin{array}{l}\text { pBS181 digested with Pst } \mathrm{I} \text {, the protruding ends } \\
\text { digested with Klenow DNA polymerase and the } \\
\text { fragment religated }\end{array}$ & This study \\
\hline
\end{tabular}

*Strain obtained from the Escherichia coli Genetic Stock Center.

transferred to polyethylene vials containing $2 \mathrm{ml}$ Optiphase 'HiSafe 3' scintillation fluid (Wallac) and the radioactivity counted in an LKB Primo liquid scintillation counter. Uptake rates are expressed in nmol sulphate $\min ^{-1}$ (g cellular protein $)^{-1}$.

\section{RESULTS AND DISCUSSION}

\section{The $y \operatorname{In} A$ gene encodes a sulphate transporter}

The $y \ln A$ ORF from B. subtilis shows homology with phosphate permeases (Mansilla \& de Mendoza, 1997) but no significant homology with proteins involved in sulphate uptake (see below). However, we have found that $y \ln A$ is transcriptionally induced by sulphate starvation, together with $c y s H$ and other genes involved in cysteine biosynthesis (unpublished results), suggesting that its gene product is a sulphate permease. To test the possibility that the $y \ln A$ gene product is involved in sulphate transport, we tried complementation of different classes of E. coli mutants unable to transport sulphate and thus to use sulphate as a sole sulphur source. Mutants affected in cysT as well as the uncharacterized cys A97 mutant are cysteine auxotrophs and they are unable to utilize sulphate as a sole sulphur source (Kredich, 1996). Strains carrying a single mutation in $c y s P$ or $s b p$ are able to utilize both sulphate and thiosulphate as a sole sulphur source, whilst the inactivation of both genes leads to cysteine auxotrophy resulting from the block in the transport of both ions (Sirko et al., 1995).

Complementation analysis was performed with plasmid pBS170 (which contains $c y s H, y \ln A$ and the $5^{\prime}$ portion of $y \ln B$, Table 1) and its derivatives: pBS181 (which includes a complete copy of $y \ln A$ ), pBS184 (containing $y \ln A$ lacking the first $60 \mathrm{bp}$ of the ORF), pBS188 (which includes $y \ln A$ without the last $140 \mathrm{bp}$ of the ORF) and pBS190, a derivative of pBS181 possessing a frameshift mutation in $y \ln A$ (Table 1). As shown in Fig. 2, only plasmids pBS170 and pBS181, containing a complete functional copy of $y \ln A$, restored the capacity of the cys A97, cysT and cysP sbp E. coli mutants to grow in minimal medium with sulphate as a sulphur source. These data strongly suggested that $y \ln A$ encodes a protein involved in sulphate transport. Moreover, the protein encoded by this gene should have a substrate recognition site since $y \ln A$ is able to bypass the requirement of E. coli for the $s b p$ and $c y s P$ genes, which encode the sulphate and thiosulphate periplasmic binding proteins (Sirko et al., 1995).

To directly prove that $y \ln A$ encodes a sulphate transporter we tested whether plasmid pBS181 could restore 


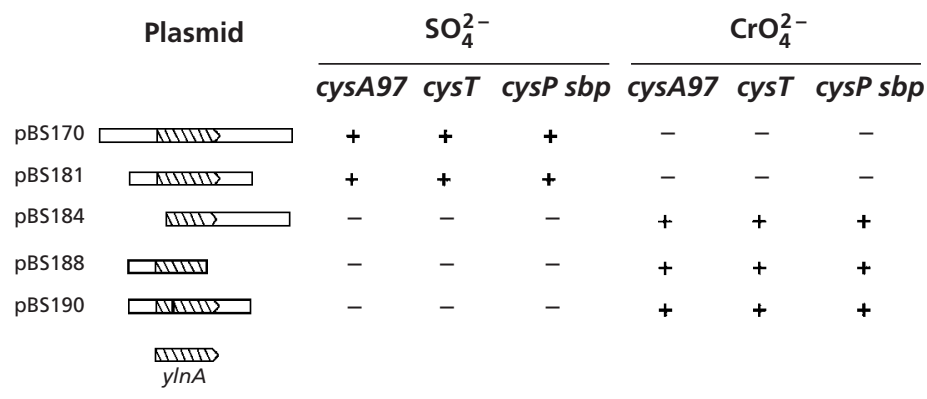

Fig. 2. Growth of $E$. coli mutants deficient in sulphate transport in the presence of different $y / n A$ region plasmids. Strains JM2314 (cysA97), EC2256 (cysT) and EC2402 (cysP sbp) transformed with the appropriate plasmid were tested for growth in minimal medium supplemented with $1 \mathrm{mM} \mathrm{MgSO}_{4}$ as a sulphur source or in LB medium with $0 \cdot 25 \mathrm{mM} \mathrm{K}_{2} \mathrm{CrO}_{4}$. - , No growth; +, good growth.

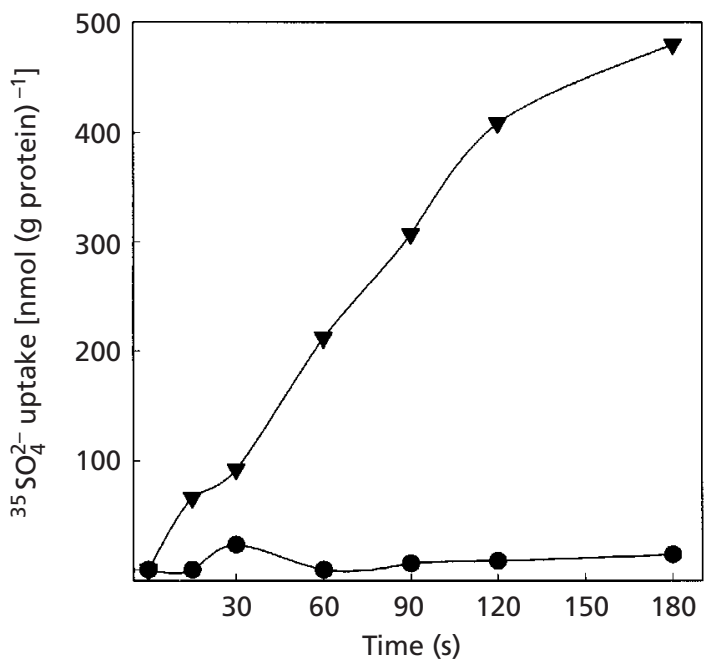

Fig. 3. Uptake of ${ }^{35} \mathrm{SO}_{4}^{2-}$ by plasmid-carrying strains. Sulphate transport was measured as described in Methods. Each datum point is the mean of three separate experiments with a mean error in transport values of less than $5 \%$. J JM2314 [pBluescript II SK(+)]; $\boldsymbol{\nabla}, J M 2314$ (pBS181).

the capacity to transport sulphate to the E. coli cys A97 strain JM2314. To this end, cultures of strain JM2314 carrying plasmids pBluescript II SK(+) or pBS181 were assayed. In whole-cell transport assays, strain JM2314 bearing pBS181 showed ${ }^{35} \mathrm{SO}_{4}^{2-}$ transport activity, whereas no measurable accumulation of radioactive sulphate was observed in strain JM2314 transformed with pBluescript II SK(+) (Fig. 3). This experiment clearly demonstrates that the $B$. subtilis $y \ln A$ gene product possesses sulphate permease activity. Thus, we have renamed this gene cysP, the letter $\mathrm{P}$ denoting a permease.

\section{Chromate sensitivity in E. coli and B. subtilis}

In Pseudomonas aeruginosa and Alcaligenes eutrophus, chromate is accumulated by sulphate uptake systems, and expression of ChrA (chromate resistance protein $\mathrm{A}$ ) leads to reduced accumulation of chromium (Cervantes et al., 1990; Nies \& Silver, 1989). Since the genome of $E$. coli does not encode ChrA homologues, resistance to chromate in this micro-organism has been associated with a deficiency in sulphate uptake. We tested whether plasmids containing $B$. subtilis cysP could confer chromate sensitivity to $E$. coli strains unable to transport sulphate. The result of this experiment showed that plasmids pBS170 and pBS181 conferred sensitivity to chromate to the cysT, cysP sbp and cysA97 mutants (Fig. 2), indicating that the cysP gene product can mediate the transport of chromate, as does the E. coli sulphate transporter system.

We have found that sulphate is able to relieve the toxicity of chromate in $c y s P^{+}$B. subtilis. In fact, strain JH642 is resistant to chromate in LB medium or in minimal media supplemented with $1 \mathrm{mM}$ sulphate (data not shown). However, in minimal media supplemented with $1 \mathrm{mM}$ glutathione as a sole sulphur source, the growth of strain JH642 is inhibited by chromate (data not shown). The toxicity of chromate in this case is relieved by the addition of $1 \mathrm{mM}$ sulphate, thus indicating that sulphate by itself leads to reduced accumulation of chromate (data not shown). These results agree with the suggestion that the B. subtilis ChrA homologues YwrA and YwrB could catalyse a chromate/sulphate antiport, exchanging sulphate for the toxic accumulated chromate (Nies et al., 1998).

\section{Expression of cysP in E. coli}

To analyse the protein encoded by $c y s P$, we used plasmid pBS181 containing cysP under the control of the T7 promoter (Table 1). This plasmid was transformed into E. coli BL21(2DE3). Induction of gene expression was done according to the method of Studier et al. (1990). Expression of the DNA insert containing cysP in pBS181 resulted in the detection of a protein of $24 \mathrm{kDa}$ (Fig. 4, lane 2). As described in the Introduction, the molecular mass calculated from the deduced primary sequence of CysP $(\mathrm{Y} \ln \mathrm{A})$ is $42.3 \mathrm{kDa}$, larger than the molecular mass of $24 \mathrm{kDa}$ estimated by the mobility of the cysP gene product. Such an aberrant migration on SDS-PAGE is 


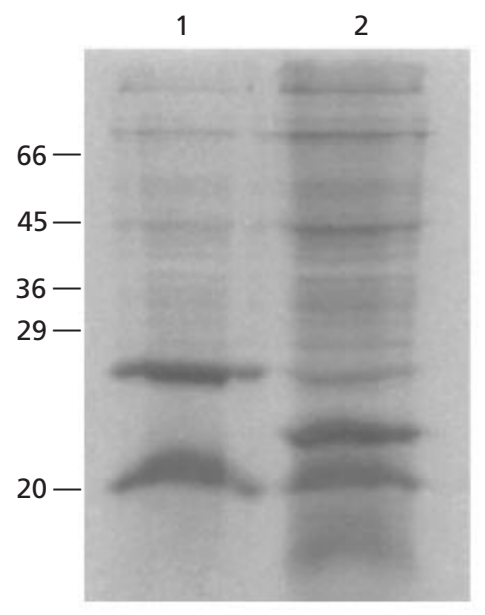

Fig. 4. Expression of $B$. subtilis cysP in E. coli BL21( $\lambda \mathrm{DE} 3)$ Cultures harbouring plasmid pBluescript II SK(+) (lane 1) and pBS181 (lane 2) were labelled with ${ }^{35} \mathrm{~S}$ ]methionine as described in the text. Samples were analysed by SDS-PAGE. The positions of molecular mass markers $(\mathrm{kDa})$ are indicated at the left.

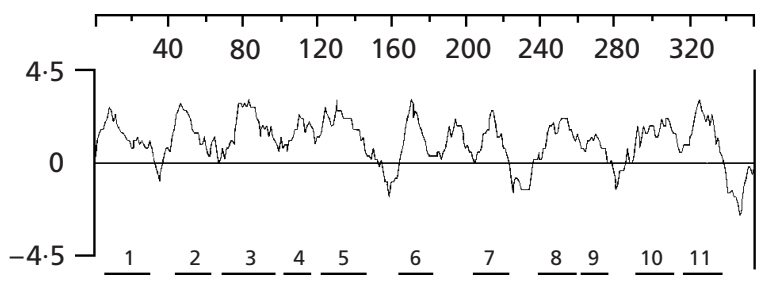

Fig. 5. Hydropathy profile of $B$. subtilis CysP. Hydropathy indices were calculated by the algorithm of Kyte \& Doolittle (1982) with a window size of 11 residues. The regions indicated by the numbered bars are the most likely to form TMSs. Amino acid residue numbers are shown on the horizontal scale.

well documented for a variety of hydrophobic proteins (Buchel et al., 1980; David et al., 1990; Maiden et al., 1987).

To analyse if indeed CysP is localized in the membrane fraction, strain BL21( $\lambda$ DE3) carrying plasmid pBS181 was labelled with $\left[{ }^{35} \mathrm{~S}\right]$ methionine. Cells were disrupted by sonication, the extracts centrifuged and labelled proteins present either in the soluble or membrane fractions subjected to SDS-PAGE. Autoradiography of the gel showed that the bulk of the $24 \mathrm{kDa}$ protein encoded by cysP is localized in the membrane fraction (data not shown).

\section{Predicted structure of CysP}

The hydropathy profile of the product of $c y s P$, determined as described by Kyte \& Doolittle (1982), shows a hydrophobic peptide with 10-12 transmembrane segments (TMSs) (Fig. 5), resembling those of other membrane-associated proteins. Moreover, a putative cleavable N-terminal signal peptide, characteristic of membrane-bound proteins, was determined in CysP using the program PSORT (Nakai, 1996).

Charge bias analysis of membrane protein topology, performed using the program TOP PRED (von Heijne, 1992) was used to predict the most likely putative TMSs of CysP. This analysis revealed that the polypeptide would contain 11 TMSs, where the $\mathrm{C}$ terminus is cytoplasmic and the $\mathrm{N}$ terminus is on the outside surface of the membrane. According to this model of CysP, several basic amino acids residues, such as lysine and arginine, would be asymmetrically distributed on both sides of the membrane. We suggest that CysP contains 20 basic amino acids located in the cytoplasmic loops of the protein, whilst the loops located on the outside face of the membrane contain two positively charged amino acids. This charge distribution is in agreement with the positive-inside rule (von Heijne, 1992). Nevertheless, the actual number of TMSs should be determined experimentally.

Analysis of the amino acid sequence of the cysP gene product using the BLAST algorithm (Altschul et al., 1997) revealed that this protein is composed of two homologous domains, called D1 and D2, possessing 69\% similarity. Domain D1 extends from residue 1 to 150 and contains five TMSs (TMS 1-TMS 5). Domain D2 extends from residue 163 to 313 and possesses TMS 6-TMS 10. This topological organization of the transporter suggests that $\mathrm{CysP}$ might have arisen by a tandem internal gene duplication event.

\section{Phylogenetic relationship}

A comparison of the primary structure of CysP with protein sequences in the databases revealed a high level of similarity to those of several phosphate permeases of both prokaryotic and eukaryotic origin. However, no significant homology was found between CysP and proteins belonging to the SulP family.

Among the putative phosphate permeases, CysP shows a similar size and the same domain organization as the archaeal transporters (Table 2). The CysP gene product of $B$. subtilis showed a high level of similarity $(67-72 \%)$ to the putative phosphate transporters of Pyrococcus horikoshii, Archaeoglobus fulgidus and Methanobacterium thermoautotrophicum. We also found that Neurospora crassa Pho- 4 and E. coli PitA proteins show significant homology with D1 in the $\mathrm{N}$-terminal region and with D2 in the C-terminal region (Table 2). Both proteins have a central region which is not homologous to CysP, which accounts for the difference in size, since both Pho-4 and PitA are larger than CysP (Mann et al., 1989; Sofia et al., 1994).

All the proteins that show significant homology with $B$. subtilis CysP belong to the inorganic phosphate transporter (Pit) family (Saier et al., 1999). Functionally characterized members of this family appear to catalyse inorganic phosphate uptake, either by proton or sodium symport (Versaw \& Metzenberg, 1995; Martinez \& Persson, 1998). 
Table 2. Amino acid identity and similarity of the CysP domains of $B$. subtilis to corresponding proteins of other organisms

\begin{tabular}{|c|c|c|c|c|c|c|c|}
\hline \multirow[t]{2}{*}{ Organism } & \multirow[t]{2}{*}{ Name or description } & \multirow{2}{*}{$\begin{array}{l}\text { GenBank } \\
\text { accession no. }\end{array}$} & \multirow{2}{*}{$\begin{array}{l}\text { Size (no. of } \\
\text { amino acids) }\end{array}$} & \multicolumn{2}{|c|}{$\mathrm{D} 1^{*}$} & \multicolumn{2}{|c|}{$\mathrm{D} 2 *$} \\
\hline & & & & $\mathrm{I}(\%)$ & $\mathrm{S}(\%)$ & $\mathrm{I}(\%)$ & $S(\%)$ \\
\hline Archaeoglobus fulgidus & Putative phosphate permease & AAB89449 & 333 & 35 & 71 & 31 & 67 \\
\hline Pyrococcus horikoshii & $\begin{array}{l}\text { Putative sodium-dependent } \\
\text { phosphate permease }\end{array}$ & BAA30231 & 318 & 33 & 69 & 30 & 72 \\
\hline $\begin{array}{l}\text { Methanobacterium } \\
\text { thermoautotrophicum }\end{array}$ & $\begin{array}{l}\text { Sodium-dependent phosphate } \\
\text { permease }\end{array}$ & AAB86351 & 326 & 33 & 69 & 28 & 68 \\
\hline Haemophilus influenzae & $\begin{array}{l}\text { Putative phosphate permease } \\
\text { HI1604 }\end{array}$ & P45268 & 420 & 31 & 69 & 31 & 69 \\
\hline Neurospora crassa & $\begin{array}{l}\text { Pho4, phosphate-repressible } \\
\text { phosphate permease }\end{array}$ & P15710 & 590 & 25 & 67 & 21 & 68 \\
\hline Escherichia coli & $\begin{array}{l}\text { PitA, low-affinity inorganic } \\
\text { phosphate permease }\end{array}$ & P37308 & 499 & 23 & 66 & 23 & 59 \\
\hline Bacillus subtilis & $\begin{array}{l}\text { YkaB, putative phosphate } \\
\text { permease }\end{array}$ & CAA05564 & 328 & 25 & 66 & 23 & 60 \\
\hline
\end{tabular}

*Domain D1 of CysP extends from residue 1 to 150 and domain D2 extends from residue 163 to 313 . Alignments were created with the CLUSTAL method (Thompson et al., 1994). I, identity; S, similarity.

\section{Concluding remarks}

The results presented here show that the cysP gene product is a membrane-bound protein with a gel electrophoresis migration corresponding to an apparent molecular mass of $24 \mathrm{kDa}$. The fact that $c y s P$ is able to restore the capacity to transport sulphate to the cys $A 97$ strain JM2314 and to relieve cysteine auxotrophy of mutants affected in both the periplasmic and membrane components of the sulphate-thiosulphate permease of $E$. coli demonstrates that its gene product is a sulphate permease. It is interesting to note that in E. coli and $S$. typhimurium, sulphate and thiosulphate share the same periplasmic transport system (Kredich, 1996). However, in B. subtilis thiosulphate might be transported by a different permease, since strain MC2620, which possesses a Tn917 insertion downstream of $c y s H$, exerting a polar effect on expression of $c y s P$, is able to grow with thiosulphate as sole sulphur source (Mansilla \& de Mendoza, 1997).

The B. subtilis cysP gene encodes a novel membraneassociated sulphate transporter, without significant homology to sulphate transporters from both prokaryotic and eukaryotic organisms. This sulphate transporter belongs to a different class of carriers, the Pit family [Transport Commission (TC) no. 2.20; Paulsen et al., 1998]. Taking into account the homology of CysP to inorganic phosphate permeases, it remains to be determined if in addition to functioning as a sulphate permease, CysP is able to transport inorganic phosphate.

It is believed that proteins of the Pit family, as well as the members of other ancient families of secondary active transporters, such as the CaCA family (TC no. 2.19) and the Amt family (TC no. 2.49), are very restricted with respect to their substrate specificities (Paulsen et al., 1998). In this work we demonstrated that CysP is able to transport sulphate; thus, the assumed function of the uncharacterized members of the Pit family as putative phosphate transporters should be reconsidered.

\section{ACKNOWLEDGEMENTS}

We gratefully acknowledge J. van der Ploeg and M. Hryniewicz for the gift of bacterial strains. This work was supported by grants from the Consejo Nacional de Investigaciones Científicas y Técnicas (CONICET) and Agencia Nacional de Promoción Científica y Tecnológica (FONCYT). M. C. Mansilla is a fellow of CONICET and D. de Mendoza is a Career Investigator of the same institution.

\section{REFERENCES}

Altschul, S. F., Madden, L. M., Schaffer, A. A., Zhang, J., Zhang, Z., Miller, W. \& Lipman, D. J. (1997). Gapped BLAST and PSI-BLAST, a new generation of protein database search programs. Nucleic Acids Res 25, 3389-3402.

Buchel, D. E., Grononborn, B. \& Muller-Hill, B. (1980). Sequence of the lactose permease gene. Nature 283, 541-545.

Cervantes, C., Ohtake, H., Chu, L., Misra, T. K. \& Silver, S. (1990). Cloning, nucleotide sequence, and expression of the chromate resistance determinant of Pseudomonas aeruginosa plasmid pUM505. J Bacteriol 172, 287-291.

David, S., Van der Rest, M. E., Driessen, A. J. M., Simons, G. \& de Vos, W. M. (1990). Nucleotide sequence and expression in Escherichia coli of the Lactococcus lactis citrate permease gene. J Bacteriol 172, 5789-5794.

Hastbacka, J., De La Chapelle, A., Mahtani, M. M. \& 12 other authors (1994). The diastrophic dysplasia gene encodes a novel sulfate transporter: positional cloning by fine-structure linkage disequilibrium mapping. Cell 78, 1073-1087.

von Heijne, G. (1992). Membrane protein structure prediction. Hydrophobicity analysis and the positive-inside rule. J Mol Biol 225, 487-497. 
Higgins, C. F. (1992). ABC transporters: from microorganisms to man. Annu Rev Cell Biol 8, 67-113.

Hoffmann, B., Strauch, E., Gewinner, C., Nattermann, H. \& Appel, B. (1998). Characterization of plasmid regions of foodborne Yersinia enterocolitica biogroup 1A strains hybridizing to the Yersinia enterocolitica virulence plasmid. Syst Appl Microbiol 21, 201-211.

Hryniewicz, M., Sirko, A., Palucha, A., Böck, A. \& Hulanicka, D. (1990). Sulfate and thiosulfate transport in Escherichia coli K-12: identification of a gene encoding a novel protein involved in thiosulfate binding. J Bacteriol 172, 3358-3366.

Johansson, P. \& Hederstedt, L. (1999). Organization of genes for tetrapyrrole biosynthesis in Gram-positive bacteria. Microbiology 145, 529-538.

Ketter, J. S., Jarai, G., Fu, Y. H. \& Marzluf, G. A. (1991). Nucleotide sequence, messenger RNA stability, and DNA recognition elements of $c y s-14$, the structural gene for sulfate permease II in Neurospora crassa. J Biochem 30, 1780-1787.

Kobayashi, T., Sugimoto, T., Saijoh, K., Fukase, M. \& Chihara, K. (1997). Cloning of mouse diastrophic dysplasia sulfate transporter gene induced during osteoblast differentiation by bone morphogenetic protein-2. Gene 198, 341-349.

Kredich, N. M. (1996). Biosynthesis of cysteine. In Escherichia coli and Salmonella typhimurium: Cellular and Molecular Biology, pp. 514-527. Edited by F. C. Neidhart and others. Washington, DC: American Society for Microbiology.

Kunst, F., Ogawawara, N., Moszer, I. \& 148 other authors (1997). The complete genome sequence of the gram-positive bacterium Bacillus subtilis. Nature 390, 249-256.

Kyte, J. \& Doolittle, R. F. (1982). A simple method for displaying the hydropathic character of a protein. J Mol Biol 157, 105-132.

Laudenbach, D. E. \& Grossman, A. R. (1991). Characterization and mutagenesis of sulfur-regulated genes in a cyanobacterium: evidence for function in sulfate transport. J Bacteriol 173, 2739-2750.

Maiden, M. C. J., Davis, E. O., Baldwin, S. A., Moore, D. C. \& Henderson, P. J. F. (1987). Mammalian and bacterial sugar transport proteins are homologous. Nature 325, 641-643.

Mann, B. J., Bowman, B. J., Grotelueschen, J. \& Metzenberg, R. (1989). Nucleotide sequence of $p h o-4^{+}$, encoding a phosphaterepressible phosphate permease of Neurospora crassa. Gene 83, 281-289.

Mansilla, M. C. \& de Mendoza, D. (1997). L-cysteine biosynthesis in Bacillus subtilis: identification, sequencing, and functional characterization of the gene coding for phosphoadenylylsulfate sulfotransferase. J Bacteriol 179, 976-981.

Martinez, P. \& Persson, B. L. (1998). Identification, cloning and characterization of a derepressible $\mathrm{Na}^{+}$-coupled phosphate transporter in Saccharomyces cerevisiae. Mol Gen Genet 258, 628-638.

Miller, J. H. (1972). Experiments in Molecular Genetics. Cold Spring Harbor, NY: Cold Spring Harbor Laboratory.

Nakai, K. (1996). Refinement of the prediction methods of signal peptides for the genome analysis of Saccharomyces cerevisiae and Bacillus subtilis. GIW-96 (Genome Informatics Workshop, Tokyo, 1996), pp. 72-81. Tokyo: Universal Academy Press.

Nies, D. H. \& Silver, S. (1989). Plasmid-determined inducible efflux is responsible for resistance to cadmium, zinc, and cobalt in Alcaligenes eutrophus. J Bacteriol 171, 896-900.
Nies, D. H., Koch, S., Wachi, S., Pietzsch, N. \& Saier, M. H., Jr (1998). CHR, a novel family of procaryotic proton motive forcedriven transporters probably containing chromate/sulfate antiporters. J Bacteriol 180, 5799-5802.

Pardee, A. B., Prestidge, L. S., Whipple, M. B. \& Dreyfuss, J. (1966). A binding site for sulfate and its relation to sulfate transport into Salmonella typhimurium. J Biol Chem 241, 3962-3969.

Paulsen, I. T., Sliwinski, M. K. \& Saier, M. H., Jr (1998). Microbial genome analyses: global comparisons of transport capabilities based on phylogenies, bioenergetics and substrate specifities. $J$ Mol Biol 277, 573-592.

Saier, M. H., Eng, B. H., Fard, S. \& 15 other authors (1999). Phylogenetic characterization of novel transport families revealed by genome analyses. Biochim Biophys Acta 1422, 1-56.

Sambrook, J., Fritsch, E. F. \& Maniatis, T. (1989). Molecular Cloning: a Laboratory Manual, 2nd edn. Cold Spring Harbor, NY : Cold Spring Harbor Laboratory.

Sirko, A., Hryniewicz, M., Hulanicka, D. \& Böck, A. (1990). Sulfate and thiosulfate transport in Escherichia coli K-12: nucleotide sequence and expression of the cysTWAM gene cluster. $J$ Bacteriol 172, 3351-3357.

Sirko, A., Zatyka, M., Sadowy, E. \& Hulanicka, D. (1995). Sulfate and thiosulfate transport in Escherichia coli K-12: evidence for a functional overlapping of sulfate and thiosulfate-binding proteins. J Bacteriol 177, 4134-4136.

Smith, F. W., Ealing, P. M., Hawkesford, M. J. \& Clarkson, D. T. (1995a). Plant members of a family of sulfate transporters reveal functional subtypes. Proc Natl Acad Sci USA 92, 9373-9377.

Smith, F. W., Hawkesford, M. J., Prosser, I. M. \& Clarkson, D. T. (1995b). Isolation of a cDNA from Saccharomyces cerevisiae that encodes a high affinity sulphate transporter at the plasma membrane. Mol Gen Genet 247, 709-715.

Sofia, H. J., Burland, V., Daniels, D. L., Plunkett, G., III \& Blattner, F. R. (1994). Analysis of the Escherichia coli genome. V. DNA sequence of the region from 76.0 to 81.5 minutes. Nucleic Acids Res 22, 2576-2586.

Spizizen, J. (1958). Transformation of biochemically deficient strains of Bacillus subtilis by deoxyribonucleate. Proc Natl Acad Sci USA 44, 1072-1078.

Studier, F. W., Rosenberg, A. H., Dunn, J. J. \& Dubendorff, J. W. (1990). Use of T7 RNA polymerase to direct expression of cloned genes. Methods Enzymol 185, 60-89.

Takahashi, H., Yamazaki, M., Sasakura, N., Watanabe, A., Leustek, T., de Almeida Engler, J., Engler, G., Van Montagu, M. \& Saito, K. (1997). Regulation of sulfur assimilation in higher plants: a sulfate transporter induced in sulfate-starved roots plays a central role in Arabidopsis thaliana. Proc Natl Acad Sci USA 94, 11102-11107.

Thompson, J. D., Higgins, D. G. \& Gibson, T. J. (1994). ClustaL w : improving the sensitivity of progressive multiple sequence alignment through sequence weighting, position-specific gap penalties and weight matrix choice. Nucleic Acids Res 22, 4673-4680.

Versaw, W. K. \& Metzenberg, R. L. (1995). Repressible cationphosphate symporters in Neurospora crassa. Proc Natl Acad Sci USA 92, 3884-3887.

Received 2 September 1999; revised 14 December 1999; accepted 4 January 2000. 